\title{
Congenital Eruption Cyst: A Case Report
}

\author{
Ramón Manuel Alemán NAVAS ${ }^{1}$ \\ María Guadalupe Martínez MENDOZA ${ }^{2}$ \\ Mário Roberto LEONARDO ${ }^{3}$ \\ Raquel Assed Bezerra da SILVA ${ }^{3}$ \\ Henry W. HERRERA ${ }^{4}$ \\ Helen Piccolo HERRERA ${ }^{4}$
}

\author{
${ }^{1}$ Department of Oral and Maxillofacial Surgery, Zacamil's Nacional Hospital, El Salvador, San Salvador \\ ${ }^{2}$ Latinamerican University, Mexico D.F, Mexico \\ ${ }^{3}$ Department of Pediatric Clinic, Preventive and Community Dentistry, Ribeirão Preto Dental School, \\ University of São Paulo, SP, Brazil \\ ${ }^{4}$ Evangelic University of El Salvador, San Salvador, El Salvador
}

\begin{abstract}
Congenital pathologies are those existing at or dating from birth. Occurrence of congenital cystic lesions in the oral cavity is uncommon in neonates. Eruption cyst (EC) is listed among these unusual lesions. It occurs within the mucosa overlying teeth that are about to erupt and, according to the current World Health Organization (WHO) classification of epithelial cysts of the jaws, EC is a separate entity. This paper presents a case of congenital EC successfully managed by close monitoring of the lesion, without any surgical procedure or tooth extraction. Eruption of the teeth involved, primary central incisors, occurred at the fourth month of age. During this time neither the child nor mother had any complication such as pain on sucking, refusal to feed, airway obstruction, or aspiration of fluids or teeth.
\end{abstract}

Key Words: congenital, eruption cyst, primary teeth, children.

\section{INTRODUCTION}

Congenital pathologies are those existing at or dating from birth. Occurrence of congenital cystic lesions in the oral cavity is uncommon in neonates and they represent a great challenge for pediatricians, pediatric surgeons, pediatric dentists, dermatologists, pathologists, and oral and maxillofacial surgeons. Various causes of intraoral cystic lesions include enteric duplication cysts, dermoid and epidermoid cyst, hemangioma, ranula, mucocele, lingual thyroid, lymphoepithelial cyst, cystic hygroma, teratoma, eruption cysts (ECs), and Bohn's nodule (1). A number of complications can arise are associated with congenital pathologies in the oral cavity: pain on sucking, refusal to feed, respiratory difficulty because of airway obstruction, aspiration of fluids or teeth when natal or neonatal teeth are present (2). Because of this, oral cysts are also of great concern to parents who may be confused and misinformed about these pathologies, generating misconceptions and myths around the newborn child. Information to parents of the pathology affecting the child and its implications is of paramount importance.

ECs occur within the mucosa overlying teeth that are about to erupt. The cyst appears as a bluish, translucent, elevated, compressible, dome-shaped lesion of the alveolar ridge, and is one of the local disturbances to eruption teeth.

In the past, EC was considered a type of dentigerous cyst (DC) occurring in the soft tissues. Whereas the typical DC develops around the crown of an unerupted tooth within the jaw bone, EC occurs within the soft tissues overlying a tooth during the eruption process. Most authors refer to EC as a cystic lesion, which is dissimilar to DC. According to the World Health Organization (WHO) classification of epithelial cysts of the jaws, EC is a separate entity (3).

Although most EC reports are in the first decade of life, only a few reports have shown this type of lesion in neonates (3-5).

Correspondence: Profa. Dra. Raquel Assed B. da Silva, Faculdade de Odontologia de Ribeirão Preto, Universidade de São Paulo, Avenida do Café, s/n, Monte Alegre, 14040-904 Ribeirão Preto, SP, Brasil. Tel: +55-16-3602-4786. Fax: +55-16-363-0999. e-mail: raquel@forp.usp.br 
This paper presents a case of congenital EC successfully managed by close monitoring of the lesion, without any surgical procedure or tooth extraction.

\section{CASE REPORT}

A Caucasian male infant, born full-term after an uncomplicated pregnancy was evaluated by his pediatrician at the moment of birth finding an intraoral mass in the anterior sector of the mandible. The patient was referred to the Department of Oral and Maxillofacial Surgery of Zacamil's Nacional Hospital, El Salvador, San Salvador for evaluation and treatment.

Physical examination revealed a $2 \times 2 \mathrm{~cm}$ diameter exophytic, soft, yellowish compressive lesion in the anterior sector of the mandible. The patient did not have feeding problems or other complications. Radiographic examination showed normal primary central and lateral incisors with no evidence of bone pathology (Fig. 1). A needle aspiration biopsy of the lesion was done, obtaining a yellow liquid similar to that obtained from dentigerous cysts. The histopathological evaluation showed the presence of cholesterol crystals compatible

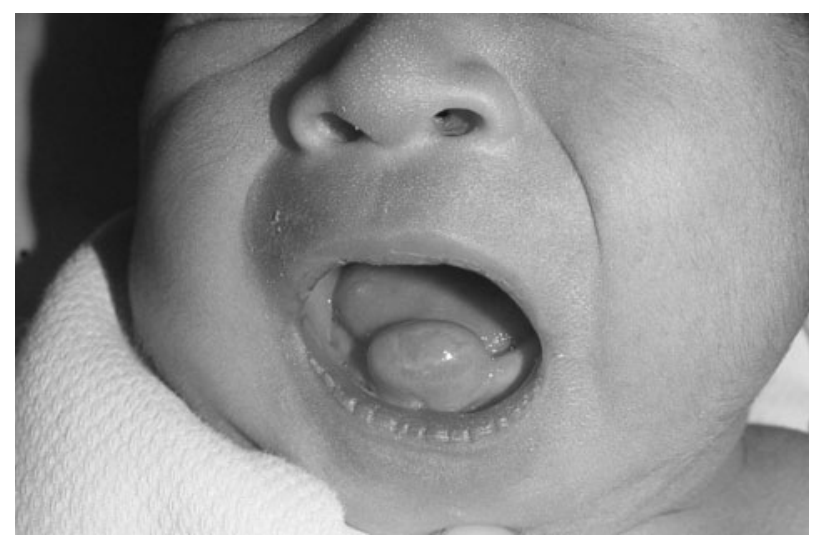

Figure 1.A 2x $2 \mathrm{~cm}$ diameter eruption cyst at the moment of birth. Notice the yellowish aspect of the lesion.

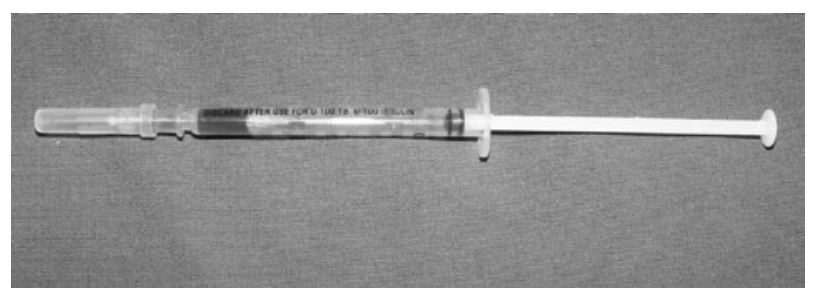

Figure 2. Cystic content obtained after needle aspiration biopsy, similar to the content obtained from a dentigerous cyst. with cystic lesions (Fig. 2). The aspiration of the lesion helped to diminish the pressure and the size of it. Also primary central incisors could be palpated under the lesion after aspiration.

The diagnosis of a congenital EC was done through clinical, radiographic and histopathological findings. Due to patient's age and the absence of feeding problems the treatment of choice was to monitor the lesion. Outpatient follow-up visits were scheduled 15 days later, and then monthly. After 1 month, the size of the lesion had diminished to $1.0 \times 0.7 \mathrm{~cm}$, and the color had changed from yellowish to a normal gingival color. By the 4th month, the lesion had disappeared completely and the central primary incisors had erupted without problems (Fig. 3). Radiographic follow up showed normal root development of the central incisors. The patient is still under control with adequate eruption sequence and complete regression of the initial lesion.

\section{DISCUSSION}

The etiology of EC is controversial. Some attribute its development to degenerative cystic changes in the reduced enamel epithelium following completion of amelogenesis, while others suggest that the cyst develops from the epithelial remnants of the dental

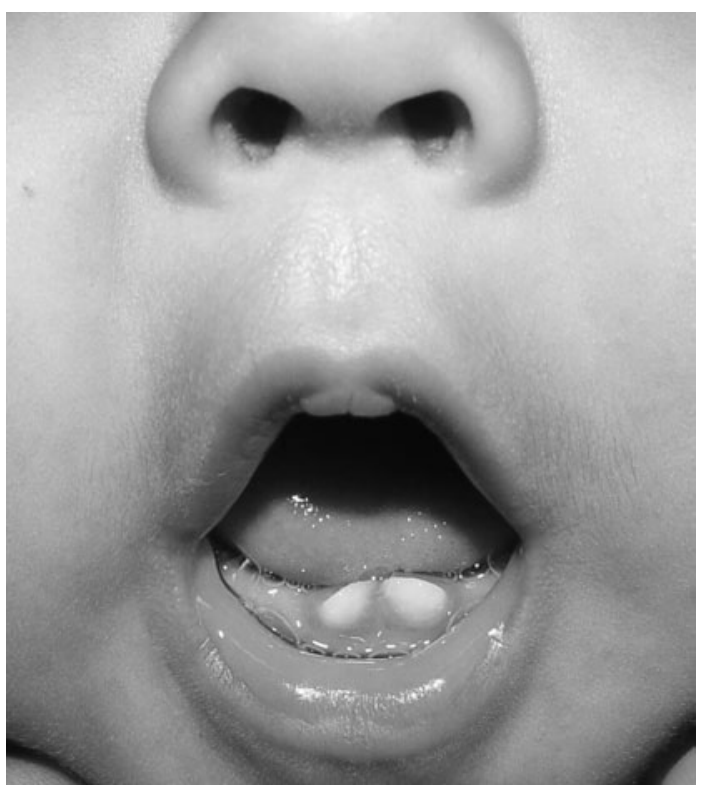

Figure 3. Four-month follow-up showing normal eruption of primary central incisors, without abnormal mobility or other pathology. 
lamina overlying the eruption tooth. The pathogenesis of EC is probably similar to that of DC. The difference is that, in EC, the tooth is hampered in breaking through to the surface by the soft tissues of the gingival rather than the bone (6). O'Hara et al. (7) reported that chronic administration of cyclosporine to neonatal dogs induced development of EC, which was reversible once the treatment was discontinued; however there are no studies in humans. In the present report, the patient was not exposed to cyclosporine.

The mean age of patients with EC varies from one study to another; Bodner et al. (3) reported an average age of 4.44 ranging from 1 month to 12 years, whilst others reported an average from 6.66 to 8.18 years (810). Most of the cases were at the first decade of life, an age when the primary dentition and many of the permanent teeth normally erupt (3). Reports of EC in extreme ages are considered rare. There are two reports of EC in patients aged 40- and 46-year-old (6). ECs are rarely observed in neonates considering that at this stage of the child's life teeth erupting are uncommon. Clark (4) reported a total of 6 ECs in newborns, on a study of approximately 3,000 births. Bodner et al. (3) reported 2 cases of neonatal cysts (3). In all cases, the size of the cysts was not reported and none of them seem to be as large as our case.

Gender predilection of EC is controversial. While some authors $(3,9)$ reported a male predilection (male:female ratio 2:1), others (10) found no gender differences or a female predilection (8). Our patient was a Caucasian male coinciding with more recent data previously reported of male Caucasian predilection.

Treatment options have been: no treatment and follow up, marsupialization or surgical extraction. The role of histopathology in establishing the final diagnosis is not essential, however, it is important to prevent any misdiagnosis, such as hemangioma, melanoma, unicystic ameloblastoma, keratinizing cystic odontogenic tumor, mucocele, mainly when the treatment is marsupialization or enucleation of the lesion (6).

EC may be associated to natal or neonatal teeth and has been classified as mature natal or neonatal when the tooth is nearly or fully developed and has relatively good prognosis for maintenance, and immature natal or neonatal when the tooth has incomplete or substandard structure, implying in poor prognosis. Removal of natal or neonatal teeth is indicated when they interfere with feeding, have highly mobility, and/or are poorly developed (2). Bodner et al. (3) in a clinical report of
24 new cases of ECs reported 2 cysts associated with natal teeth. In this report, one of the teeth was treated with extraction and the other one was treated without extraction. In the present case, after needle aspiration of the cyst, central incisors where palpable under the cyst, but the decision of preserving them was taken because they did not have hypermobility, they were not interfering with feeding, and did not cause discomfort to the mother or the child. We waited cyst regression and normal eruption of teeth, which took place by the fourth month of age.

Although the histopathological analysis is not essential to establish the final diagnosis, a needle aspiration biopsy would definitely confirm the fluid filled aspect, ruling out solid lesions. The evaluation of the aspirated cystic content may demonstrate the presence of cholesterol crystals presenting a slightly yellow color and low viscosity. As in the present report, cholesterol crystals have been described as a frequent component of the cyst capsule and fluid. The cystic content should present a slightly yellow color and low viscosity (6).

Unlike other odontogenic cysts, where radiography is essential for diagnosis, EC is not detectable on radiographic examination because there is usually no bone involvement. Even so, radiography is highly recommended for evaluation of the morphology of the involved tooth or its surrounding jaw bone (6).

The present case of congenitalEC was successfully managed by close monitoring of the lesion, without any surgical procedure or teeth extraction. Parents were well informed about the pathology and its implications. Both child and mother had no complications during feeding and normal eruption of primary teeth occurred by the 4th month. Although in this case monitoring the lesion was the ideal approach, the treatment of choice must be case specific with adequate analysis of clinical and radiographic findings.

\section{RESUMO}

Patologias congênitas são aquelas que aparecem ao nascimento. A ocorrência de lesões císticas congênitas na cavidade bucal é rara em recém-nascidos. O cisto de erupção (CE) pode ser considerado como lesão rara que se localiza na mucosa que recobre um dente que está próximo do momento de sua erupção. De acordo com a classificação de cistos epiteliais dos maxilares, descrita pela Organização Mundial da Saúde (OMS), os CE são considerados uma entidade distinta. O presente relato descreve um caso clínico de um cisto congênito de erupção tratado com sucesso somente pelo acompanhamento da lesão, sem a necessidade de nenhuma intervenção cirúrgica ou extração dentária. A erupção dos dentes 
envolvidos (incisivos centrais decíduos) ocorreu aos 4 meses de idade e durante este período não houve reclamações da mãe e/ou da criança em relação a dor para sucção, recusa para se alimentar, obstrução das vias aéreas e aspiração de fluidos ou de dentes.

\section{REFERENCES}

1. Mohta A, Sharma M. Congenital oral cysts in neonates: report of two cases. Oral Surg Oral Med Oral Pathol Oral Radiol Endod 2006;102:e36-38.

2. Rao RS, Mathad SV. Natal teeth: Case report and review of literature. J Oral Maxillofac Pathol 2009;13:41-46.

3. Bodner L, Goldstein J, Sarnat H. Eruption cysts: a clinical report of 24 new cases. J Clin Pediatr Dent 2004;28:183-186.

4. Clark WB: A survey of eruption cysts in the newborn. Oral Surg Oral Med Oral Pathol 1962;15:917.
5. Ricci HA, Parisotto TM, Giro EM, de Souza Costa CA, Hebling J. Eruption cysts in the neonate. J Clin Pediatr Dent 2008;32:243246.

6. Woldenberg Y, Goldstein J, Bodner L. Eruption cyst in the adult-a case report. Int J Oral Maxillofac Surg 2004;33:804-805.

7. O'Hara AJ, Collins T, Howell JM. Gingival eruption cysts induced by cyclosporine administration to neonatal dogs. J Clin Periodontol 2002;29:507-513.

8. Seward MH. Eruption cyst: an analysis of its clinical features. J Oral Surg 1973;31:31-35.

9. Anderson RA. Eruption cysts: a retrograde study. J Dent Child 1990;57:124-129.

10. Aguilo L, Cibrian R, Bagan JV, Gandia JL. Eruption cysts: Retrospective clinical study of 36 cases. ASDC J Dent Child 1998;65:102-106.

Accepted June 22, 2010 